\title{
Adaptability of Strawberry (FragariaananassaDuch) in Lanao Del Sur, Philippines
}

\author{
Roland C. Almorado \\ College of Agriculture, Mindanao State University -Main Campus, \\ Marawi City, Lanao del Sur, Philippines
}

\begin{abstract}
The study was conducted at the College of Agriculture, Mindanao State University, Marawi City, Lanao del Sur, Philippines with the following objectives: 1) to test the adaptability of three varieties of strawberry (Florida, Haranoka and BSU-Pierre); 2) to determine which variety adapts the best; and 3) to identify insect pests and diseases affecting its production in the province. Results showed that the three varieties did not differ significantly in terms of mean number of days from transplanting to flowering, flowering to fruit maturity, number of flowers, runners, developed fruits and fruit weight. All varieties adapted well to Lanaodel Sur conditions. Insect pests of strawberries identified were aphids, cutworm, and tussock moth, leaf feeding beetles, and ants while Angular Leaf Spot was the major disease affecting strawberry production.
\end{abstract}

Keywords: strawberry, Florida, Haranoka, BSU-Pierre.

\section{Introduction}

Strawberry (Fragaria x ananassaDuch.), belongs to Rosaceae family and genus Fragaria, which is one of the most important fruit crops cultivated worldwide. Strawberries are aggregate fruits, fleshy, juicy and red in color. It has green leafy cap and the stem adom its crown. Strawberry has enlarged receptacle and the seeds are on the outside skin. Ellagic acid is also found in strawberry which believed to be anticarcinogenic

It is known to be adaptive in high elevation areas with an altitude of 1,300-2,400 meters above sea level and temperature ranging from $8-24^{\circ} \mathrm{C}$ - generally cool climate, fairy long dry season, abundant irrigation and well distributed rainfall. Presently, strawberries are the most important fruit and berry crop growing successfully on a commercial scale in Benguet Province, Cordillera Administrative Region (CAR), and Philippines. The cool climate gives the La Trinidad and some parts of Baguio City, Philippines the advantage in the production of such high value crop. Commercial production has increased since its introduction with an average yields of 15.8 tons/ha and is expected to continue to expand as growers take an increasing share of the local market. Eshghi et al. (2007) pointed out in their study that in Iran setting, strawberry cultivars adaptation, quality, fruits, breeding, production and biotechnology are top priority as subjects for study.

Turkben (2008) studied on the propagation of strawberries that in good quality. He used runner plants of strawberry cultivar using three different rooting media. Findings revealed that there were no differences were observed with respect to rooting media, but differences were noticed in terms of node formations and development.

Likewise, study of Jose et al. (2011) found out that strawberry day-neutral cultivar supply is very limited. Results of the study conducted by Dolgun (2006) experimenting strawberry plants planted in rooted plugs in mist propagation and mulched in black beds under high tunnels found out that planting strawberry through plug plants are effective in production of strawberry in eastern Mediterranean climatic conditions. 
On the other hand, soil quality will also affect strawberry cultivar development. According to Calica et al., (2018) soil quality and nutrients significantly affect and influence the growth and fruit quality of strawberry. Moreover, they also found out that plant-to-plant spacing significantly influence strawberries yield. Li, Li, Gordon, Asiedu \& Hu (2010) pointed out that light and water management is very important to consider to achieve high yield and fruits quality of strawberries. Temperature and rainfall patterns also affect strawberry propagation.

In the Philippines, strawberries are novelty in Mindanao and, as a result, fetch a very attractive price in the market. The lure of a substantial increase in income enticed some farmers in Bukidnon Province to shift from vegetable farming to strawberry cultivation. Their knowledge was greatly enhanced by a series of trainings on practices of hydroponics, mulching and organic farming of strawberries. The successful venture of strawberry production and processing in Bukidnon as exemplified by the Epol Strawberry Farmers Association offers an enormous possibility of augmenting the lives of low-income farmers in Lanaodel Sur. Both Bukidnon and Lanaodel Sur are endowed with cool climate which is an important requirement for strawberry production. Lanaodel Sur, particularly, Marawi City is nested on a plateau with an altitude of 833 meters above sea level. The cool temperature of the area ranges between 16.0 to $22.0{ }^{\circ} \mathrm{C}$ with an this study assessed the adaptability of three strawberry varieties cultivated in Lanaodel Sur conditions which will serve as basis for recommending the production of the commodity in the area.

\section{Materials and Methods}

Limited number of strawberry runners particularly Haranoka and BSU-Pierre from Epol, Bukidnon were transplanted at the nursery seedbed of the They were allowed to produce runners for planting purposes together with Florida which had been transplanted ahead of the two varieties. The study runs from August 30 to December 5, 2010.

\section{Varieties Used}

The varieties of strawberry used in this study included the following:

1. Florida - a high yielding variety with good resistance to crown rot.

2. Haranoka - is known because of its aroma and sweetness, even though they are only mediumsized.

3. BSU-Pierre - good producer of runners with round, medium-sized fruits.

\section{Experimental Design}

The experiment was laid out in Complete Randomized Design (CRD). Thirty runners were used for each variety.

\section{Treatments}

Variable $1(\mathrm{~V} 1)=$ Florida; $\quad$ Variable $2(\mathrm{~V} 2)=$ Haranoka; $\quad$ Variable $3(\mathrm{~V} 3)=$ BSU-Pierre

\section{Cultural Management Practices}

Strawberry runners of Florida, Haranoka and BSU-Pierre were raised in a 1x10 meters seedbed (Figure 1). Soil was cultivated thoroughly and mixed with sawdust and sand. Runners were transplanted at a distance of $40 \mathrm{~cm}$ between hills and $35 \mathrm{~cm}$ per row. Complete fertilizer (14-14-14), calcium nitrate and zinc phosphate were applied basally following the standard recommendation. Side dressing of fertilizer was done one month after transplanting.

Shading was provided to protect the plants from excessive heat of the sun and too much water due to constant rains. Drip irrigation was employed to meet the water requirements of the plants. Seedbed was mulched with black polyethylene sheet to control weeds and prevent water loss during dry weeks. 


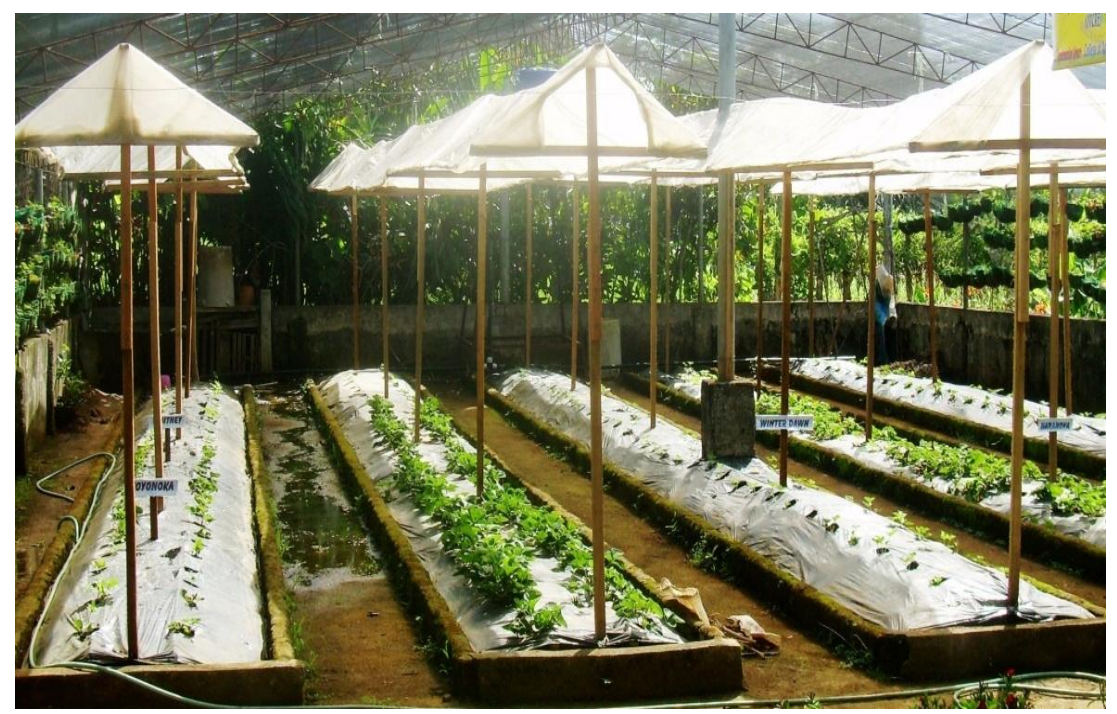

Figure 1: The Experimental Set-up at the Nursery, College of Agriculture, MSU

\section{Data Collection}

Ten data plants were taken randomly from the plot. The fruits were handpicked and gathered according to variety. Data collected included the following:

1. Counting the number of days from the day the seedlings were transplanted until the production of first flowers (Transplanting to Flowering)

2. Counting the number flowers produced per plant (Flowers per Plant).

3. Counting the number of days from first flowering to maturity (Number of Days from Flowering to Fruit Maturity).

1. Counting the number of runners produced per plant (Runners per Plant).

2. Counting the number of developed fruits (Fruits Developed).

3. Fruit weight was recorded. Average weight of developed fruits per variety was computed using the formula:

Average fruit weight (grams) $=$ total weight of fruits

total number of fruits

\section{Collection and Identification of Insects}

Monitoring and collection of insects and other arthropods associated with strawberries were done weekly. Collected specimens were preserved in vials filled with ethyl alcohol. They were identified by Dr. Myrna Ballentes, an insect taxonomist of the Department of Entomology, Central Mindanao University, Musuan, Bukidnon.

\section{Disease Assessment}

Montalban (2009) reported that the major disease attacking strawberry was Angular Leaf Spot (ALS). The same methodology (Figure 2) in disease assessment was employed in this study. The following data were gathered to assess the severity of the disease.

1. Number of Leaves. Counting the number of leaves produced per plant every week.

2. Number of Leaves Infected per Plant. Counting the number of infected leaves per plant every week.

3. Disease Severity. Rating the leaf infection (\%) using the numerical rating and rating scale below:

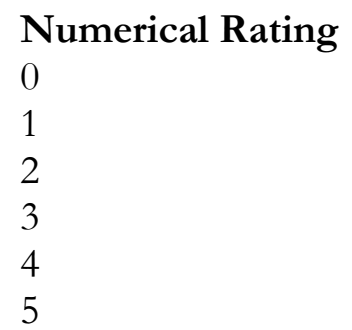

\section{Descriptive Rating}

Healthy plant

$1 \%-10 \%$ Infected Leaves

$11 \%-25 \%$ Infected Leaves

26\%-40\% Infected Leaves

41\%-60\% Infected Leaves

60\%- above Infected Leaves 


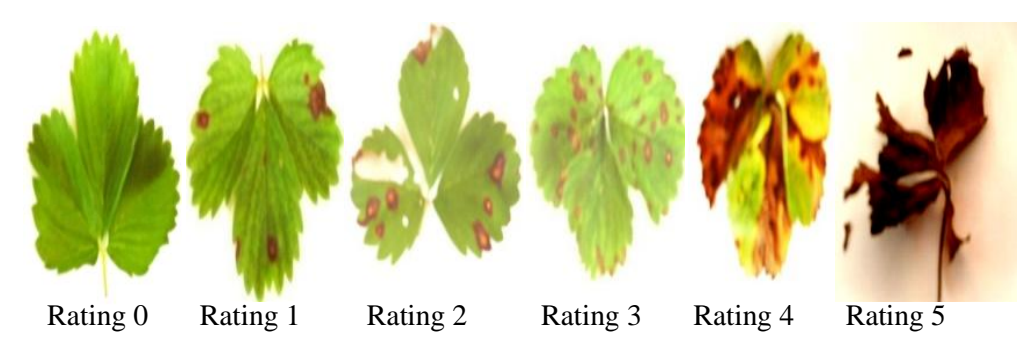

Figure 2: The Rating Scale for Disease Severity

\section{Results}

Days from Transplanting to Flowering

\begin{tabular}{|l|l|l|l|l|l|l|}
\hline \multirow{2}{*}{ PARAMETERS } & \multicolumn{4}{l|}{ VARIETY } \\
\cline { 2 - 7 } & \multicolumn{2}{l|}{ BSU -Pierre } & \multicolumn{2}{l|}{ Florida } & \multicolumn{2}{l|}{ Haranoka } \\
\cline { 2 - 7 } & Mean & Range & Mean & Range & Mean & Range \\
\hline $\begin{array}{l}\text { Transplanting to flowering } \\
\text { (days) }\end{array}$ & $57.00^{\text {ns }}$ & $\begin{array}{l}53.44- \\
61.400^{\text {ns }}\end{array}$ & $\begin{array}{l}45.00- \\
56.00\end{array}$ & $43.53^{\text {ns }}$ & $\begin{array}{l}38.20- \\
48.00\end{array}$ \\
\hline Flowers per plant & $1.37^{\text {ns }}$ & $1.31-1.42$ & $1.63^{\text {ns }}$ & $1.21-2.01$ & $1.55^{\text {ns }}$ & $1.42-1.66$ \\
\hline $\begin{array}{l}\text { Flowering to fruits maturity } \\
\text { (days) }\end{array}$ & $20.56^{\text {ns }}$ & $\begin{array}{l}17.18- \\
23.50\end{array}$ & $22.56^{\text {ns }}$ & $\begin{array}{l}21.19- \\
21.01^{\text {ns }}\end{array}$ & $\begin{array}{l}20.62- \\
22.10\end{array}$ \\
\hline Runners per plant & $0.67^{\text {ns }}$ & $0-1.00$ & $1.18^{\text {ns }}$ & $1.00-1.28$ & $1.16^{\text {ns }}$ & $1.00-1.30$ \\
\hline Fruits developed & $1.38^{\text {ns }}$ & $1.32-1.42$ & $1.46^{\text {ns }}$ & $1.24-1.60$ & $1.53^{\text {ns }}$ & $1.38-1.71$ \\
\hline Weight of fruits (grams & $2.5^{\text {ns }}$ & $0.97-3.34$ & $2.33^{\text {ns }}$ & $1.69-3.08$ & $2.87^{\text {ns }}$ & $2.70-3.12$ \\
\hline
\end{tabular}

Table 1: Growth and Yield Performance of three Varieties of Strawberries grown in MSU Marawi

Legend: Mean and range of days from transplanting to flowering, number of flowers per plant, days of flowering to fruit maturity, number of runners, number of fruits developed and weight of fruits. College of Agriculture, Mindanao State University, Marawi City.August 30 - December 5, $2010{ }^{\text {ns-not significant }}$

Haranoka was the earliest to bear flowers which ranged from 38.20-48.00 days ( $x=43.53$ ) followed by Florida which ranged from 45.00-56.00 days $(x=51.40)$ while the longest to bear flowers was BSU-Pierre which ranged from 53.44-61.00 days $(\mathrm{x}=57.0)$. Statistical analysis, however, revealed no significant differences among the three varieties from days of transplanting to flowering.

\section{Number of Flowers Produced}

Florida produced the highest number of flowers (Figure 3) which ranged from 1.21-2.01 ( $x=1.63)$ followed by Haranoka which ranged from 1.42- $1.66(\mathrm{x}=1.55)$ while BSU-Pierre produced the least number of flowers which ranged from 1.31-1.42 $(\mathrm{x}=1.37)$. Statistical analysis again showed no significant difference among the three varieties. Watters (2018) said that many environmental factors will affect flowering and running behavior of strawberry. The common environmental factors are temperature and day length.
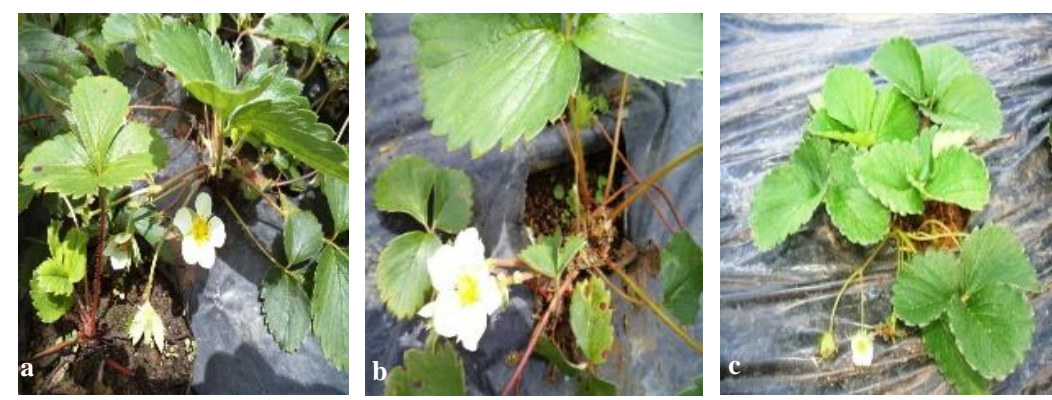

Figure 3: Flowers of a) Haranoka; b) Florida; c) BSU-Pierre 


\section{Days from Flowering to Fruit Maturity}

Days from flowering to fruit maturity were longest for Florida which ranged from 21.19-25.20 days $(x=22.56)$ followed by Haranoka which ranged from 20.62-22.10 days $(x=21.01)$ while BSU-Pierre had the least number of days from flowering to maturity among the three varieties ranging from 17.18-23.50 days $(x=20.56)$. Statistical analysis, however, revealed that this difference was not significant.

\section{Total Number of Runners}

Both Florida and Haranoka produced almost the same number of runners (Figure 4) which ranged from 1.00-1.30 $(x=1.26)$ and 1.00-1.28 $(x=1.18)$ respectively, while BSU-Pierre produced the least which ranged from $0-1.00(x=.67)$ but these differences did not differ significantly.

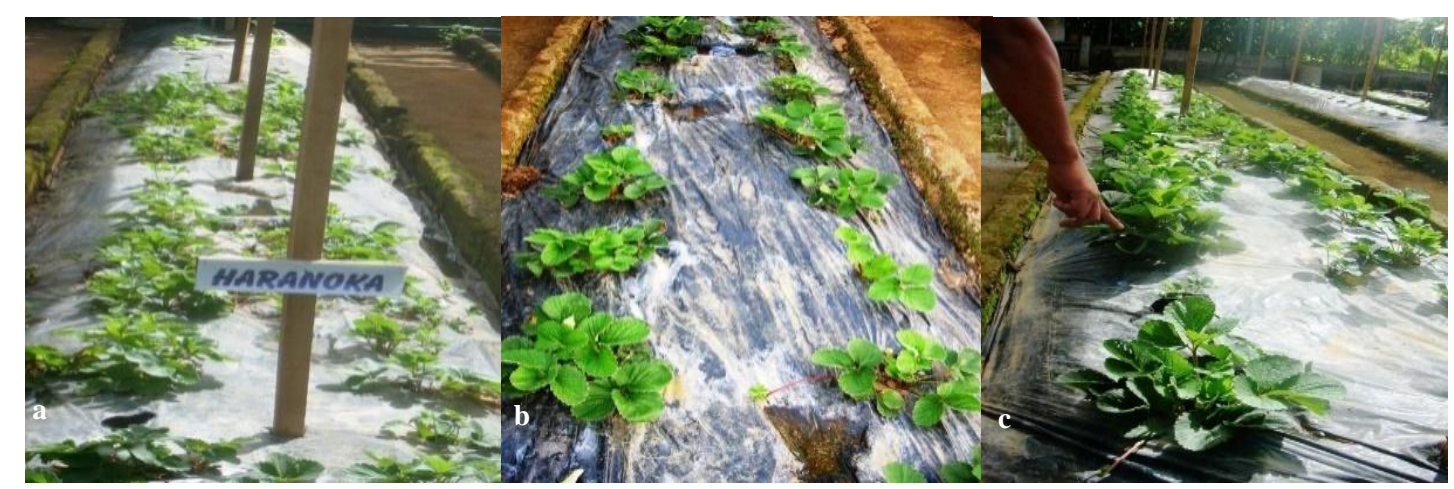

Figure 4: Runners of a) Haranoka; b) Florida; c) BSU-Pierre

\section{Mean Number and Weight of Fruits (grams)}

The mean number and weight of the fruits (Figure 5) from the three varieties varied slightly but not significantly. Haranoka produced more fruits which ranged from 1.38-1.71 $(x=1.53)$ compared with Florida which ranged from 1.24-1.60 $(\mathrm{x}=1.46)$ and BSU-Pierre with 1.32-1.42 $(\mathrm{x}=1.38)$. Statistical analysis revealed no significant difference among the three varieties. The berries of Haranoka were also slightly heavier which ranged from 2.70-3.12 grams $(x=2.87)$ followed by BSU-Pierre with 0.973.34 grams $(x=2.51)$ and Florida with 1.69-3.08 grams $(x=2.33)$. Statistical analysis showed that the mean fruit weight of the varieties also did not differ significantly.

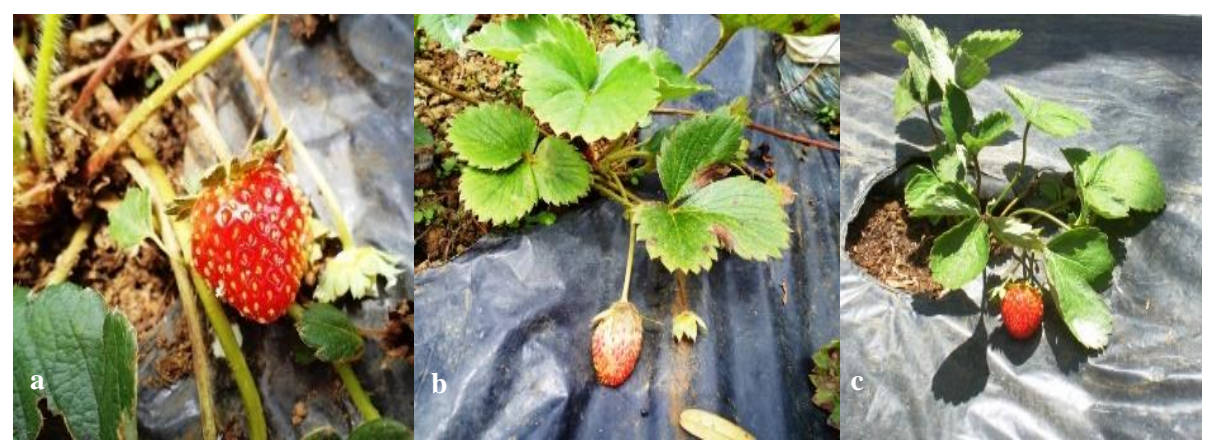

Figure 5: Ripe Berry of a) Haranoka; b) Florida; c) BSU-Pierre

\section{Insect Pests of Strawberry}

Ten species of insect pests were found associated with strawberries (Table 2) which included the aphids (Aphis gossypii), cutworm (Spodopteralitura), tussock moth (Orgyia sp.), leaf-feeding beetles (Monolepta sp. andAulacophorasp), adult beetle (Leucopholisirrorata), curculionid beetle (Metapocyrtussp), mealybugs (Pseudococcidae) and ants (Solenopsissp). According to Tirado et al., (2010), change in temperature and rainfall pattern impacted on the patterns of bacteria, viruses, parasites and fungi occurrence, the same with foodborne diseases. 
Table 2: Insect pests identified infesting strawberries cultured at the College of Agriculture, Mindanao State University, Marawi City. August 30, 2011 - December 5, 2011

\begin{tabular}{|c|l|l|}
\hline Class/Order & Family/Subfamily/Genus & $\begin{array}{l}\text { Common Name/Scientific } \\
\text { Name }\end{array}$ \\
\hline 1. Coleoptera Scarabaeidae & Chrysomelidae: Galerucinae & $\begin{array}{l}\text { Beetle, Monolepta sp., } \\
\text { Aulacophora sp. } \\
\text { Adult beetle, Leucopholis sp. } \\
\text { Weevil, Metapocyrytus sp. }\end{array}$ \\
\hline 2. Homoptera & Curculionidae & $\begin{array}{l}\text { Aphid, Aphis gossypii } \\
\text { Undetermined mealybug }\end{array}$ \\
\hline 3. Hymenoptera & $\begin{array}{l}\text { Aphididae } \\
\text { Pseudococcidae }\end{array}$ & $\begin{array}{l}\text { Ant, Solenopsis } \\
\text { Ant, undetermined sp. }\end{array}$ \\
\hline 4. Lepidoptera & $\begin{array}{l}\text { Noctuidae } \\
\text { Lymantriidae }\end{array}$ & $\begin{array}{l}\text { Cutworm, Spodopteralitura } \\
\text { Tussock moth, Orgyia sp. }\end{array}$ \\
\hline
\end{tabular}

\section{Major Disease of Strawberry}

Strawberries, like other crops, are also affected with various diseases. The most prevalent disease that infected strawberries was the Angular Leaf Spot disease (ALS). It is a bacterial disease caused by Xanthomonas fragariae, a pathogen highly specific to wild and cultivated strawberry (Legard et al., 2003). ALS is an important worldwide disease on strawberry. In U.S., it ranks 6th in economic importance (Sorensen, 1997). The most prevalent disease that infected strawberries was the Angular Leaf Spot disease (ALS). Table 3 shows the mean number of infected leaves and disease severity of the three varieties of strawberry grown under MSU-Marawi, Lanaodel Sur condition. Leaf infection and disease severity by ALS were not significantly different among the three varieties. During severe epidemics, the pathogen also can cause lesions on the calyx of fruit that are identical to foliar lesions and when severe, can make the fruit unmarketable (Legard et al., 2003). The tissue with older damage eventually dies and dries up, giving leaves a ragged appearance. Haranoka leaf infection was slightly higher which ranged from 3.21-3.63 ( $\mathrm{x}=3.37)$ followed by Florida 3.08-3.68 ( $\mathrm{x}=3.29)$ while BSU-Pierre had lower leaf infection which ranged from 2.91-3.37 ( $\mathrm{x}=3.12)$. Disease severity ranged from 3.64-3.83 $(x=3.76)$ for Haranoka, followed by BSU-Pierre which ranged from 3.38-3.84 $(\mathrm{x}=3.57)$ and Florida which ranged from 3.50-3.60 ( $\mathrm{x}=3.55)$.

Table 3: Mean number of leaves, number of infected leaves by Angular Leaf Spot Disease (ALS), and Disease severity on three varieties of strawberry. College of Agriculture, Mindanao State University, Marawi City, August 30-December 5, 2010

\begin{tabular}{|c|c|c|c|c|c|c|}
\hline \multirow{3}{*}{ PARAMETERS } & \multicolumn{6}{|c|}{ VARIETY } \\
\hline & \multicolumn{2}{|c|}{ BSU -Pierre } & \multicolumn{2}{|c|}{ Florida } & \multicolumn{2}{|c|}{ Haranoka } \\
\hline & Mean & Range & Mean & Range & Mean & Range \\
\hline Leaves per plant & 6.61 & $5.29-7.86$ & 6.77 & $5.93-8.00$ & 6.47 & $5.94-7.26$ \\
\hline Leaves infected per plant & 3.12 & $2.91-3.37$ & 3.29 & $3.08-3.68$ & 3.37 & $3.21-3.63$ \\
\hline Disease severity & $3.57^{\mathrm{ns}}$ & $3.38-3.84$ & $3.55^{\mathrm{ns}}$ & $3.50-3.60$ & $3.76^{\mathrm{ns}}$ & $3.64-3.83$ \\
\hline
\end{tabular}

Legend: $n s=$ not significant

\section{Discussion}

The production of flowers and fruits are the best indicators of adaptation of strawberry plants. Statistically, results showed that the three varieties did not differ significantly in terms of mean number of days from transplanting to flowering, number of flowers per plant, number of days from flowering to fruit maturity, number of runners per plant, number of developed fruits and weight of fruits (grams). Cocco et al. (2010) conducted a study on development and fruit yield of strawberry plants and concluded that to have a more vigorous transplant planting materials, larger runner tips strawberry is selected. Moreover, to improve early fruits yield and decreasing the strawberry plant vegetative growth, growing time of runner tips should be increased. The study of Palencia, Martínez, Medina \& López-Medina (2013) about strawberry propagation revealed that temperature and solar radiation has linear relationship to strawberry production. They concluded that climate change will reduce strawberry productions in general. 
Pontillos (2009) found out that ten species of insect pests were found associated with the strawberries grown at the nursery. One of it are aphids which are small (1-3 $\mathrm{mm}$ long), soft-bodied, pear-shaped insects that sucked plant sap, removing nutrients, reducing yields, and, in some cases, causing disease. Symptoms of damage include leaf discoloration, flattened appearance, bent, white or distorted leaves, and dying or dead patches (large bronzy or brown areas) in the field. Tirade et al., (2010) mentioned that viruses, bacteria, parasites and fungi impacted the growth and physiology of strawberries. Leeuwis \& Hall (2008) pointed out that plant and pest infestations promote food borne diseases.

According to the American Society for Horticultural Science (2016), there are many factors that can damage strawberry propagation, usually environmental conditions and soil $\mathrm{pH}$. Successful strawberry farming will be obtained with proper cultivar selection, soil fertility, soil $\mathrm{pH}$ and management. Likewise, Watters (2018) have the same contention by pointing out those environmental factors really affect flowering and running behavior of strawberries. These factors include temperature, day length and seasons. Gupta et al. (2016), supported the idea of Watters (2018) and Horticultural Science (2016) stating that the most significant abiotic stress for strawberry plant growth and development is the low temperature. Morphogenesis and other physiological responses of strawberries are also influence by light intensity which will lower the rate of photosynthesis thus limiting the production yield of strawberries.

Menzel \& Smith (2014) pointed out in their study that season greatly affects the strawberry fruits production. Moreover, growth of the whole plant, growth of flowers, fruit development, and leaf expansion are significantly related and influence by the seasons. In Mindanao, particularly in Lanaodel Sur province, the season is almost in uniform in the whole year round. Base on the data obtained from the study, the three varieties did not show any substantial difference in all measured parameters. They grew, bore both flowers and fruits, hence, they adapted the climate of Lanaodel Sur. Therefore strawberry farming is feasible to be grown in the province.

\section{Summary, Conclusion and Recommendation}

This study was about the adaptability of Strawberry (FragariaananassaDuch) in Lanaodel Sur conditions. Three (3) varieties of strawberry were used which include Haranoka, Florida and BSUPierre and the study was conducted at the Nursery of the College of Agriculture, Mindanao State University. This research aimed to 1) to test the adaptability of the strawberry varieties under Lanaodel Sur conditions; 2) to check which variety best adapted in the area; and 3) to identify the major pests and diseases affecting the commodity.

Adaptability was assessed based on mean number of days from transplanting to flowering, number of flowers, number of days from flowering to fruit maturity, number of runners, number of developed fruits and its weight. Haranoka was the earliest to bear flowers $(x=43.53)$ followed by Florida $(x=51.40)$ and BSU-Pierre $(x=57.00)$. Florida produced more flowers $(x=1.63)$, followed by Haranoka $(x=1.55)$ and BSU-Pierre $(x=1.37)$. Statistical analysis showed no significant differences among the three varieties in terms of days from transplanting to flowering and number of produced flowers. The mean number of days from flowering to fruit maturity was slightly earlier for BSUPierre $(x=20.56)$ followed by Haranoka $(x=21.01)$ and Florida $(x=22.56)$. This variation was not significantly different when subjected to statistical analysis.

The three varieties differed slightly in their capacity to produce runners with Florida producing more $(x=1.26)$ followed by Haranoka $(x=1.18)$ and BSU-Pierre $(x=0.67)$. Similarly, there was slight variation in their capacity to produce fruits including their weights with Haranoka producing more $(x=1.53)$ and heavier fruits $(x=2.87$ grams), followed by Florida $(x=1.46)$ with fruits of lighter weight $(x=2.33)$. BSU-Pierre produced the least $(x=1.38)$ with a heavier weight compared to Florida $(\mathrm{x}=2.51)$. Results obtained by this study proved that the three strawberry varieties adapted to Lanaodel Sur condition hence they can be grown here.

Ten species of insect pests were considered injurious to strawberries They included aphids (Aphis gossypir), cutworm (Spodopteralitura), tussock moth (Orgyia sp.), leaf-feeding beetles (Monolepta sp. and Aulacophorasp), adult beetle (Lencopholisirrorata), curculionid beetle (Metapocyrtussp), mealybugs (Pseudococcidae) and ants (Solenopsissp). The most prevalent insect pest was aphids. Their infestation 
caused unsightly appearance of strawberries. The most prevalent disease that infected the three varieties was the Angular Leaf Spot (ALS) caused by Xanthomonasfragariae. Further studies on varietal evaluation and cultural management practices is recommended to find out more promising cultivars that will best adapt to Lanaodel Sur. There is also an urgent need to conduct fertilizer studies to find out the optimum rate needed to boost strawberry production.

\section{References}

American Society for Horticultural Science. (2016). Producing strawberries in high-pH soil at high elevations. Retrieved from https://phys.org/news/2015-04-strawberries-high-ph-soil-high-elevations.html\#jCp.

Cocco, C., Andriolo, J. L., Erpen, L., Cardoso, F. L., \& Casagrande, G. S. (2010). Development and fruit yield of strawberry plants as affected by crown diameter and plantlet growing period . Pesquisa Agropecuária Brasileira, 45(7).

Dolgun, O. (2006). Yield Performance of Strawberry (fragaria $\mathrm{x}$ ananassa). Plug Plants in Eastern Mediterranean. Climatic Conditions International Journal of Agricultural Research, 1 (3), 280-285.

Eshghi, S., Abdi, G., Tafazoli, E., \& Yavari, S. (2007).Strawberry Research and Biotechnology in Iran. Middle Eastern and Russian Journal of Plant Science and Biotechnology, 1(1), 39-41.

Leeuwis, C., \& Hall, A. (2008). Food safety and climate change. FAO conference on food security and the challenges of climate change and bioenergy, Food and Agriculture Organization of the United Nations. Retrieved from http://www.fao.org/3/a-i3334e.pdf.

Gupta, S. M., Agarwal, A., Dev, B., Kumar, K., Prakash, O., \& Arya, M. C. (2016). Assessment of photosynthetic potential of indoor plants under cold stress. Photosynthetica, 54(1), 138-142.

Ijaz, M., Noor, N., Shahjahan, M., Hassan, Z., Abbas, K., \& Calica, P. (2018).Variations in Growing Media and Plant Spacing for the Improved Production of Strawberry (Fragariaananassa cv. Chandler). Philippine Journal of Science, 147(4), 711-719.

Legard, D., Ellis, M., Chandler, C., \& Price, J. (2004). Integrated management of strawberry diseases in winter fruit production areas. The strawberry: a book for growers. Dr. Norman F. Childers Publications Gainesville: FL.

Li, H., Li, T., Gordon, R. J., Asiedu, S. K., \& Hu, K. (2010). Strawberry plant fruiting efficiency and its correlation with solar irradiance, temperature and reflectance water index variation. Environmental and Experimental Botany, 68,165-174.

Jose, M., López-Aranda, Carmen, S., Bielinski, M., Santos, Luis, M., Pedro, D., \& Juan, J. (2011). Strawberry Production in Mild Climates of the World: A Review of Current Cultivar Use. International Journal of Fruit Science. 11(3), 232-244.

Menzel, C., \& , Smith, L. (2014). The growth and productivity of 'Festival' strawberry plants growing in a subtropical environment. New Zealand Journal of Crop and Horticultural Science, 42(1), 60-75.

Montalban, M. C. M. (2009). Control of angular leaf spot disease in Strawberry (Fragariaananassa) (Undergraduate Thesis) .College of Agriculture, Mindanao State University.Marawi City.

Palencia, P., Martínez, F., Medina, J. J., \& López-Medina, J. (2013). Strawberry yield efficiency and its correlation with temperature and solar radiation. Horticultura Brasileira, 31(1).

Pontillo, P. M. L. (2009). Insect pests and associated arthropods of Strawberry (Fragariaananassa) (Undergraduate Thesis). College of Agriculture, Mindanao State University.Marawi City.

Sorensen, J. (1997). The rhizosphere as a habitat for soil microorganisms. In J. D. V. Elsas, J. T. Trevors, \& E. M. H. Wellington (Eds.), Modern soil microbiology (Vol. 56, pp. 21-45). New York: Marcel Dekker. Books in soils, plants, and the environment.

Tirado M. C., Clarke, R., Jaykus, L. A., Mcquatters-Gollop, A., \& Frank, J. M. (2010). Climate change and food safety: A review. Food Research International, 43(1), 1745-1765.

Turkben, C. (2008). Propagation of Strawberry Plants in Pots: Effect of Runner Order and Rooting Media. Journal of Biology and Environmental Sciences, 2(4), 1-4.

Watters, S. (2018). Researchers find gene that may greatly increase strawberry production, University of Maryland. Retrieved from https://umdrightnow.umd.edu/news/umd-researchers-find-gene-maygreatly-increase-strawberry-production. 